\title{
Design and Implementation of a Low
}

Power Wind Turbine Emulator

Through the Induction Motor-

Permanent Magnet Generator

\section{Arrangement}

David-Felipe Bajonero-Sandoval; Jeyson Sanabria-Vargas; César-

Leonardo Trujillo-Rodríguez

Citation: D.-F. Bajonero-Sandoval, J. Sanabria-Vargas, and C.-L.

Trujillo-Rodríguez, "Design and Implementation of a Low Power Wind

Turbine Emulator Through the Induction Motor-Permanent Magnet

Generator Arrangement," Revista Facultad de Ingeniería, vol. 29 (54),

e10530, 2020. https://doi.org/10.19053/01211129.v29.n54.2020.10530

Received: January 22, 2020; Accepted: March 24, 2020;

Published: April 01, 2020

Copyright: This is an open-access article distributed under the terms of the $\underline{\mathrm{CCBY}}$

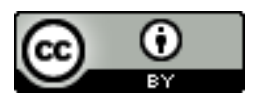

Competing interests: The authors have declared that no competing interests exist. 


\title{
Design and Implementation of a Low Power Wind Turbine Emulator Through the Induction Motor- Permanent Magnet Generator
}

\section{Arrangement}

\author{
David-Felipe Bajonero-Sandoval ${ }^{1}$ \\ Jeyson Sanabria-Vargas ${ }^{2}$ \\ César-Leonardo Trujillo-Rodríguez ${ }^{3}$
}

\begin{abstract}
This paper presents the design and construction stage of a low power wind turbine emulator, used at the laboratory level, to reproduce different wind profiles. There are several types of wind emulators, among which the wind tunnel emulators stand out. These emulators use a motor with a propeller on their axis to obtain the desired wind speed. However, in the present work -and done from a computer- speed control is developed for a three-phase induction motor, thus driving a permanent magnet generator. The motor-generator group is controlled through a program developed in the Labview software. Also, it has the particularity of operating automatically, being able to load different speed data. Such data is associated with a particular power that takes into account the selected wind profile and can operate through manual control of the wind speed. However, this depends on the frequency given. The emulator operation is validated experimentally through two scenarios: the first one
\end{abstract}

\footnotetext{
${ }^{1}$ Universidad Distrital Francisco José de Caldas (Bogotá-Distrito Capital, Colombia). ORCID: 0000-0002-18212226 .

${ }^{2}$ Universidad Distrital Francisco José de Caldas (Bogotá-Distrito Capital, Colombia). ORCID: 0000-0002-02147626.

3 Ph. D. Universidad Distrital Francisco José de Caldas (Bogotá-Distrito Capital, Colombia). cltrujillo@udistrital.edu.co. ORCID: 0000-0002-0985-1472.
} 
emulates the curve presented by the Eolos turbine and subsequently compares the results obtained, whereas the second one loads the wind profile of Uribía-Guajira -a region in Colombia- achieving that the emulated wind profile can be accurately seen in the loaded wind profile.

Keywords: permanent magnet generator; three-phase induction motor; wind emulator; wind turbine.

\section{Diseño e implementación de un emulador para una turbina eólica de baja potencia a través del arreglo motor de inducción-generador de imanes permanentes}

\section{Resumen}

En este artículo se presenta la etapa de diseño y construcción de un emulador de una turbina eólica de baja potencia, el cual se utiliza a nivel de laboratorio, con el fin de reproducir diferentes perfiles de viento. Existen varios tipos de emuladores eólicos entre los que se destacan los de túnel de viento, estos utilizan un motor con hélice en su eje para obtener la velocidad del viento deseada. Sin embargo, en el presente trabajo se desarrolla un control de velocidad, desde un computador, para un motor de inducción trifásico, impulsando así, un generador de imanes permanentes. El conjunto de equipos motor-generador es controlado a través de un programa desarrollado en el software Labview. Además, tiene la particularidad de operar de manera automática, pudiendo cargar diferentes datos de velocidad, los cuales se encuentran asociados a una potencia en particular teniendo en cuenta el perfil de viento seleccionado, así como operar a través de un control manual de la velocidad del viento, pero en función de la frecuencia. La operación del emulador se valida de forma experimental a través de dos escenarios, el primero emulando la curva presentada por la turbina Eolos y posterior comparación de los resultados obtenidos, y la segunda cargando el perfil de viento de Uribía-Guajira, en Colombia, consiguiendo que el perfil de viento emulado logre verse fiel al perfil de viento cargado.

Palabras clave: emulador eólico; generador de imanes permanentes; motor de inducción trifásico; turbina eólica. 


\section{Desenho e implementação de um emulador para uma turbina eólica de baixa potência através do conserto motor de indução-gerador de ímãs permanentes}

\section{Resumo}

Neste artigo apresenta-se a etapa de desenho e construção de um emulador de uma turbina eólica de baixa potência, o qual utiliza-se a nível de laboratório, com o fim de reproduzir diferentes perfis de vento. Existem vários tipos de emuladores eólicos, entre os quais se destacam os de túnel de vento, estes utilizam um motor com hélice em seu eixo para obter a velocidade do vento desejada. Porém, no presente trabalho desenvolve-se um controle de velocidade desde um computador para um motor de indução trifásico, impulsando assim, um gerador de ímãs permanentes. O conjunto de equipamentos motor-gerador é controlado através de um programa desenvolvido no software Labview. Ademais, tem a particularidade de operar de maneira automática, podendo carregar diferentes dados de velocidade, os quais encontram-se associados a uma potência em particular, tendo em conta 0 perfil de vento selecionado; também, pode operar através de um controle manual da velocidade do vento, mas em função da frequência. A operação do emulador valida-se de forma experimental através de dois cenários: o primeiro emulando a curva apresentada pela turbina Eolos e com a posterior comparação dos resultados obtidos, e a segunda carregando o perfil de vento de Uribía-Guajira, na Colômbia, conseguindo que o perfil de vento emulado permita ver-se fiel ao perfil de vento carregado. Finalmente, apresentam-se as conclusões.

Palavras chave: emulador eólico; gerador de ímãs permanentes; motor de indução trifásico; turbina eólica. 


\section{INTRODUCTION}

The current precarious environmental situation, result of global pollution, shows that there will be an energy-environmental crisis due to high levels of pollution and the depletion of most non-renewable natural resources. Consequently, it is essential to exploit renewable energy, one of these being wind power [1].

The demand for energy generation through alternative sources has been growing globally, approaching 25\% per year. This growth has been driven by an increase in global demand for electricity and the rising cost of non-renewable fuels, among others [2].

Electricity generation from renewable energy sources managed to reach $21 \%$ and $22.8 \%$ of the global generation in 2012 and 2014 respectively. From these figures, $3.1 \%$ corresponds to energy produced from wind power [3]. Moreover, the production of electricity from this resource is an excellent alternative for overpopulated areas. Countries such as Canada and China, among others, have established ambitious development goals, seeking to continue the exploitation of this energy source due to the challenges of acceptance in local communities [4], [5]. Results such as the $8.75 \mathrm{MW}$ of wind power installed offshore in 2014 are the result of major technological advances and the time dedicated to developing this type of energy production [4].

In Colombia, wind energy is also one of the alternatives the country has to supply the increase on energy demand. According to the UPME expansion plan, it is estimated that in the next few years, $474 \mathrm{MW}$ of wind power will be installed in the northern part of the Guajira department, which would replace $250 \mathrm{MW}$ of coal-based thermal energy [6]. Given the importance that this type of alternative energy has for the country, it is necessary to generate spaces for researching on this energy source. Thus, the prototype developed seeks to serve as a tool for the study of systems based on wind power that can be interconnected to the electrical network and at the same time, can work in isolation as well. This can be achieved through the emulation and manipulation of wind profiles from different areas, done in a controlled way.

This paper presents the design, implementation and experimental validation of a low power wind turbine emulator and is structured as follows: In section 1, the 
introduction is presented; section II describes the materials and methods. Furthermore, it presents the main characteristics that a wind emulator must have to establish the parameters and objective functions for the design and implementation of the emulator in question. Section III presents the experimental validation of the implemented emulator operating not only manually (data provided by the manufacturer of the Eolos turbine) but also automatically (loading the wind profile of the Uribía-Guajira region in Colombia). Additionally, these results are discussed. Finally, the last section presents conclusions.

\section{MATERIALS AND MetHOdS}

An experimental methodology and a quantative approach is used in this research The main characteristics that wind turbine emulators should have are investigated and design is proposed. Such design is tailored to the requirements of the problem to be addressed (low power emulators with the possible incidence in electrical microgrids). Finally, the development is validated through the implementation and a set of experimental tests.

\section{A. Features of Wind Turbine Emulators}

Wind emulators aim to reproduce the static and dynamic behavior in a controlled environment of wind turbines without the need to rely on the existence of the actual wind turbine or the actual wind resource [7].

Fig. 1 shows the conversion process of a conventional wind turbine as well as some of its components, in which the wind energy is used to move a generator (transformation of mechanical energy into electrical energy). In this figure, a gearbox is displayed, which can be ignored at the time of the emulator implementation by using a permanent magnet generator [8]. This provides, in turn, the mechanical torque to the electric generator [9]. 


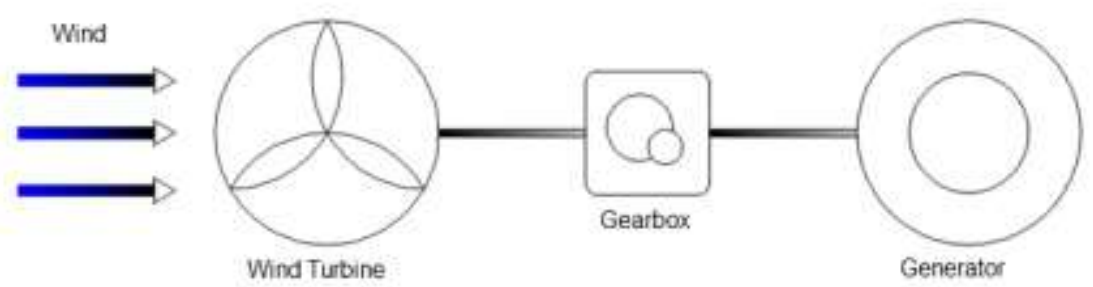

Fig. 1. Diagram of a wind turbine.

Generally speaking, wind emulators seek to replace wind speeds with a profile entered into a computer or micro-processing system, whereas wind turbines do so with a DC motor, thus establishing two constituent sections of the system. The first one corresponds to the mechanical section (motor-generator coupling), whilst the second one is related to the software developed for interface purposes, which allows interaction with the user and the corresponding motor speed control. Such sections are described below.

1) Electromechanical Section. Most of the wind emulators based on motorgenerator have the particularity of using a DC motor that emulates the wind turbine, being the input current one of the parameters to be manipulated to control the wind speed. On the other hand, the generator used is characterized by being an induction generator, also called a permanent magnet generator, as can be seen in the literature consulted [10-11]. The selection of such a generator is directly related to the wind turbine -or turbines- to be emulated. For example, when the electric generator is induction or permanent magnet motor and the wind turbine to be emulated is of low speed, it is necessary to either have a generator with a high number of poles or not to exceed it above the rated revolutions per minute. Taking these aspects into consideration, section 3 presents the generator used as well as the reason for its use, which will allow the definition of the prototype developed.

2) Software section. In wind emulators, the associated software seeks -above allto allow the compilation of the characteristic parameters of the turbine's mathematical model so that it can be simulated and allow a particular output power value to be obtained as a result. Such a result takes into account the wind speed 
recorded in the wind profiles, the maximum power curve of the generator, the turbine model and any variable that affects the value of such power [12].

Wind turbine emulators are considered highly dependent on the equipment developed for their implementation. Hence, limits and restrictions are established from power and type of turbine to be emulated. Consequently, this generates the use of a certain speed control strategy. Finally, the type of computer tool used will determine the ease of use and scope of action of the application, as well as its interaction with the user from an appropriate interface.

\section{B. Emulator Design}

Taking into account the characteristics that wind turbine emulators based on a motor-generator must-have, an emulator was developed consisting of an induction motor which acts as a wind turbine, a permanent magnet generator with an encoder, and a 3 HP frequency converter to control the rotation speed of the motor. The data is entered through a program developed in LabView and the communication between the electromechanical part and the software is done through a National Instruments data acquisition card (NI USB-6008, 12 Bits), as can be seen in Fig. 2.

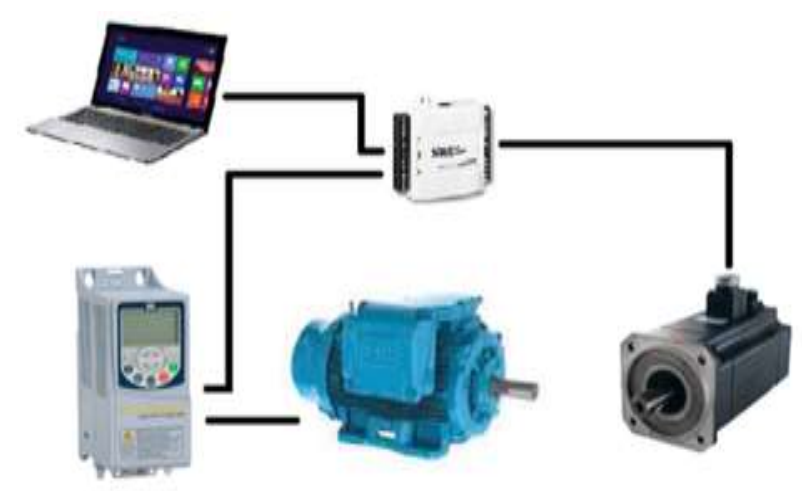

Fig. 2. Arrangement of wind turbine emulator equipment.

1) Equipment Selection. An Induction motor, used as a wind turbine, will have to act as a wind turbine that constantly changes speed when the wind speed increases or decreases. The selected motor was a WEG three-phase squirrel-cage induction motor, 2 HP (1.5 kW),1800 rpm, 220/240. 
Variable speed drive, which is in charge of the motor speed control. The variable speed drive chosen was the WEG CFW 500. It also offers a vector or scalar control option.

Permanent magnet synchronous generator, $800 \mathrm{~W}$. The great advantage of this type of generator is the elimination of brushes and reduction systems, which translates into savings in maintenance and space. The chosen generator has a speed encoder that plays an important role in designing the control system.

NI 6008 USB, National Instruments data acquisition card, which allows acquiring values of real variables to digitize them and generate control actions through a program developed in LabView.

2) Motor-generator Characterization. Once the electromagnetic components have been selected, their functioning must be verified when they are operating in order to recognize the parameters that allow establishing direct relationships with the operation of wind turbines and wind generators. To characterize the motor-generator group, the motor speed is controlled utilizing the CFW500 variable speed drive, changing the frequency in small proportions $(0.5 \mathrm{~Hz})$, from $3 \mathrm{~Hz}$ to $65 \mathrm{~Hz}$. Subsequently, current and voltage measurements are made to know the working power reached by the generator, as this depends specifically on the system frequency and the speed at which the induction motor rotates.

The data recorded in the test show the operation of the equipment when it works feeding a load of $10 \Omega$, as presented in the results in Fig. 3 .

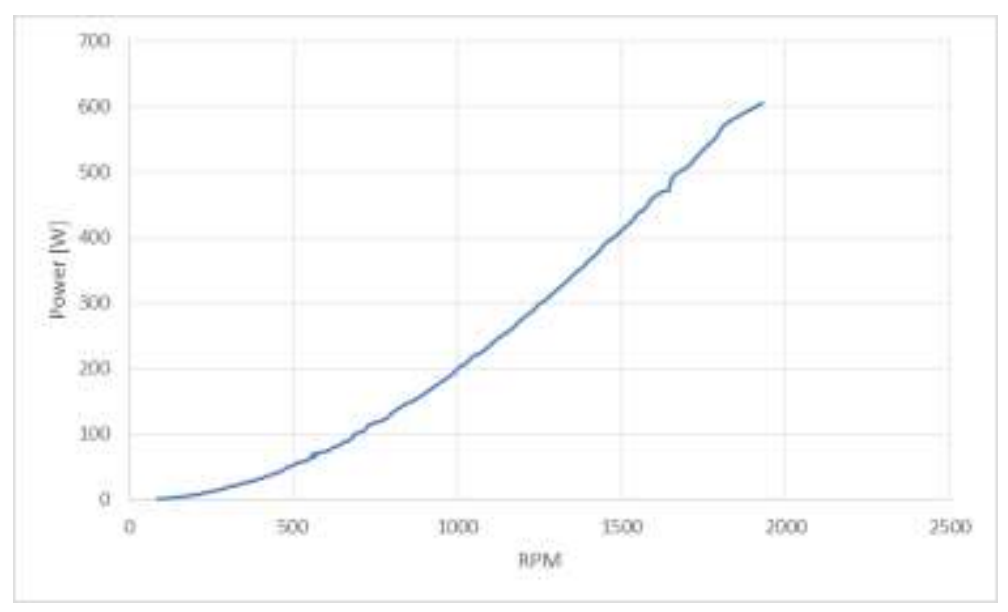

Fig. 3. Characterization of the motor-generator group. 
3) Turbine to be Emulated. Taking into account that the selected generator reaches a power of $800 \mathrm{~W}$, the emulator will only be able to emulate turbines with powers equal to or less than the power defined above.

Consequently, within the turbines that were studied, and to select the one which is best adapted to the emulation process, the following were found: Air 30, Air 40, Wattnier $1 \mathrm{~kW}$, Bornay 600 and Eolos of $600 \mathrm{~W}$ and $1000 \mathrm{~W}$ respectively.

The chosen turbine was the Eolos $600 \mathrm{~W}$, whose power vs wind speed curve is shown in Fig. 4.

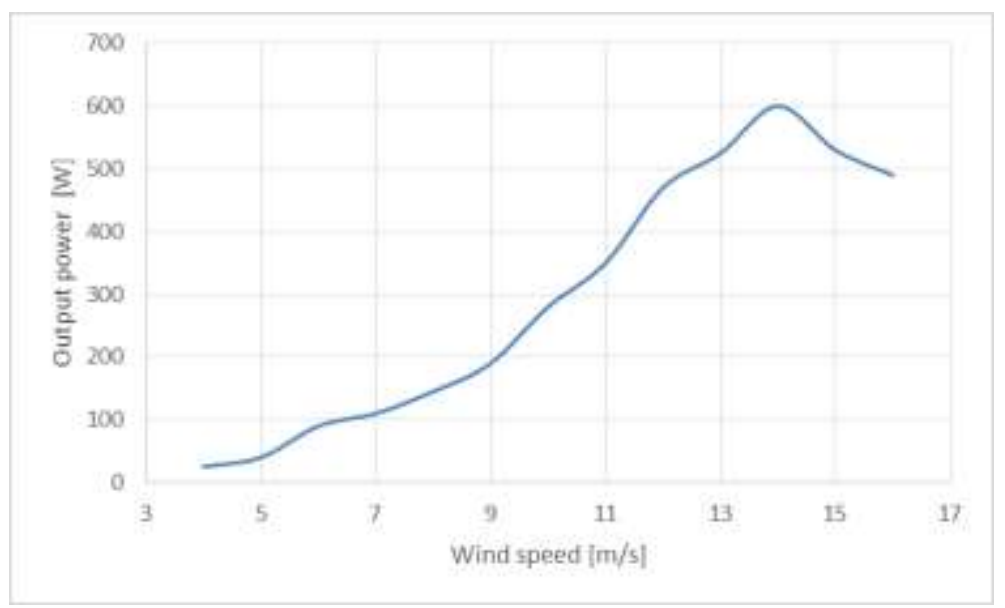

Fig. 4. Eolos 600W turbine output power curve.

Such a turbine to be emulated was selected, among other things, because of the speed range it offers power generation (between $3 \mathrm{~m} / \mathrm{s}$ and $14 \mathrm{~m} / \mathrm{s}$ ), being this the range in which wind turbines with architectural integration as well as and wind turbines operate. In addition to this, it was selected because the generator of this equipment is very similar in its construction to that of the generator used for the emulator.

\section{4) Relationship Between Frequency and Wind Speed Depending on Power.}

With the data obtained from the characterization of the motor-generator and the power data provided by the turbine manufacturer (Table 1), an equation that relates wind speed with the power generated is obtained through polynomial regression. 
Table 1. Power data gave by the manufacturer and generated by the motor-generator equipment.

\begin{tabular}{|c|c|c|c|}
\hline Power [W] & Wind Speed [m/s] & RPM Emulator & Frequency [Hz] \\
\hline 25 & 4 & 341 & 12 \\
\hline 40 & 5 & 439 & 15 \\
\hline 90 & 6 & 673 & 23 \\
\hline 110 & 7 & 722 & 25 \\
\hline 145 & 8 & 840 & 29 \\
\hline 190 & 9 & 982 & 33.5 \\
\hline 280 & 10 & 1202 & 41 \\
\hline 350 & 11 & 1361 & 46.5 \\
\hline 470 & 12 & 1627 & 55.5 \\
\hline 525 & 13 & 1730 & 59 \\
\hline 600 & 14 & 1928 & 66 \\
\hline 530 & 15 & 1730 & 59 \\
\hline 490 & 16 & 1657 & 57 \\
\hline
\end{tabular}

This is a sixth-order polynomial regression and is presented in equation (1).

$$
\frac{0.0093 X^{6}-0.3811 X^{5}+5.7936 X^{4}-41.0893 X^{3}+143.84 X^{2}-201.26 X}{117.73}=Y
$$

Where $X$ represents the wind speed and $P$ the generated power.

As it will be explained later, equation (1) is then entered into the program developed in Labview so that it has - as input parameters - the wind speed values entered manually or preloaded as a wind profile. This has to be done in order to obtain a desired output power value and thus emulate the behaviour of the selected turbine. It should be noted that selecting another turbine implies the regeneration of an equation that allows the correlation stated above.

5) Control Implementation. The developed software aims to allow users to enter a wind profile to see what the behavior of the selected turbine maybe, working under the wind speed conditions described in such a profile.

The selected software, as mentioned above, was Labview by National Instruments, which manages a graphic programming environment and has facilities for handling different communication technologies. Another important feature that influenced the selection of LabView was the possibility of performing a data acquisition process using a National Instruments card.

Because the permanent magnet generator has an encoder whose signal is sent to the data acquisition card - together with the generated voltage and current values it is possible, through mathematical processing, to establish the speed and therefore the revolutions per minute at which the wind emulator is rotating. 
The interface allows the user to enter the wind speed they want to associate. Therefore, the programme needs to be able to enter different wind speeds in a period. This is achieved through a matrix linked to a case cycle that defines the working time of the entered wind profile simulation. With the average signal and the signal entered by the user, the error is calculated and entered into a PID block. The constants of such a controller were tuned in LabView from the experimental response of the emulator using the Ziegler-Nichols method. This allows the variable of interest (speed) to be controlled, which is used subsequently in equation (1) to determine a power output similar to that of the previously selected wind turbine.

The final scheme of the emulator designed and presented in this article can be seen in Fig. 5

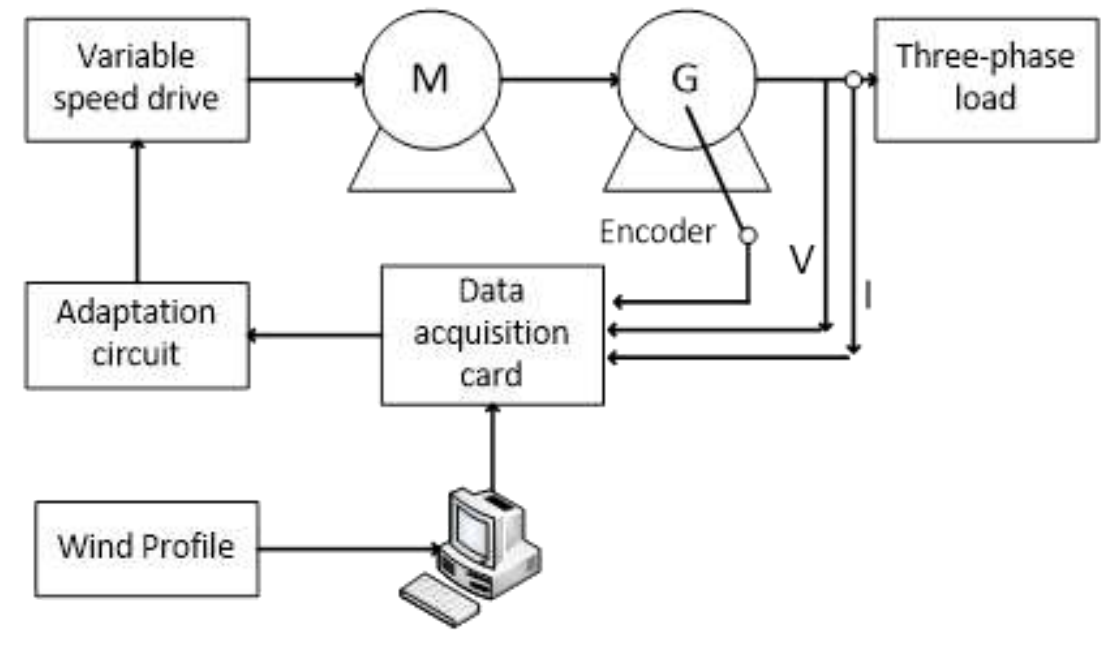

Fig. 5. General diagram of the wind turbine emulator.

\section{ResULTS AND Discussion}

The wind turbine emulator developed is shown in Fig. 6 and can be separated into three structural parts, an electromechanical part, one corresponding to the data acquisition circuits and another one to the software. 


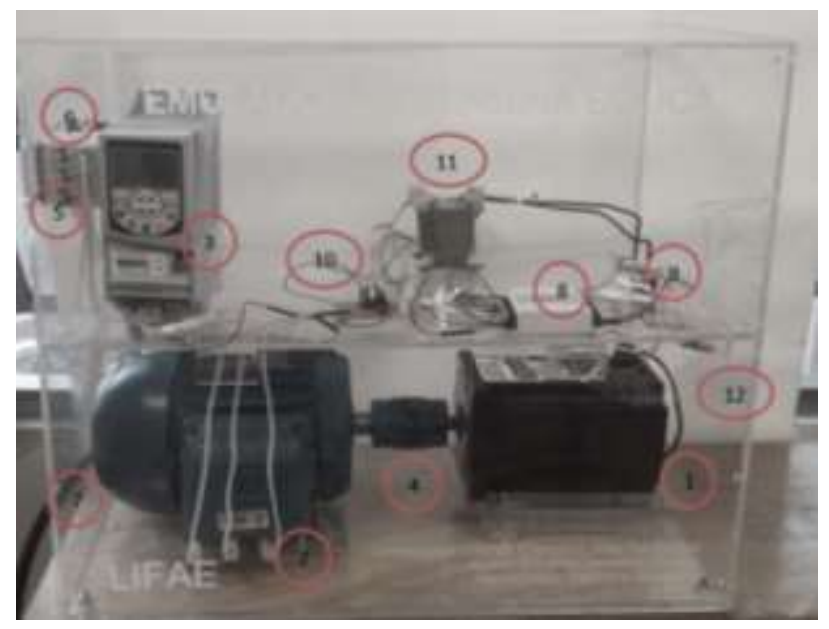

Fig. 6. Parts and components of the wind emulator prototype.

Electromechanical parts of the emulator:

1. Permanent magnet generator

2. WEG three-phase induction motor

3. 3HP WEG three-phase inverter

4. Motor generator coupling

5. Breaker $25 \mathrm{~A}$

6. Fuses

7. Power connector

Data acquisition parts:

1. NI 6008 USB DAQ data acquisition card

2. ASC712 20 A Current sensor

3. USB DAQ-PC cable and non-inverting amplifier circuit

4. AC $120 / 14-5 \mathrm{~V}$ Transformer

5. Charge connection point

Emulator software:

1. The window for entering the wind profile.

2. The window for monitoring the behavior and activity of the emulator. The emulator presents two operating options: The first one is one in which it is possible to load different speed data into the developed software. Such data are associated with a particular power that takes into account the selected wind profile. 
The second operation option is manual control of the wind speed, which depends on the frequency.

Fig. 7 and Fig. 8 show the two interface screens. In the former one, the wind profile is entered, whereas, in the latter one, the operation of the emulator can be seen.

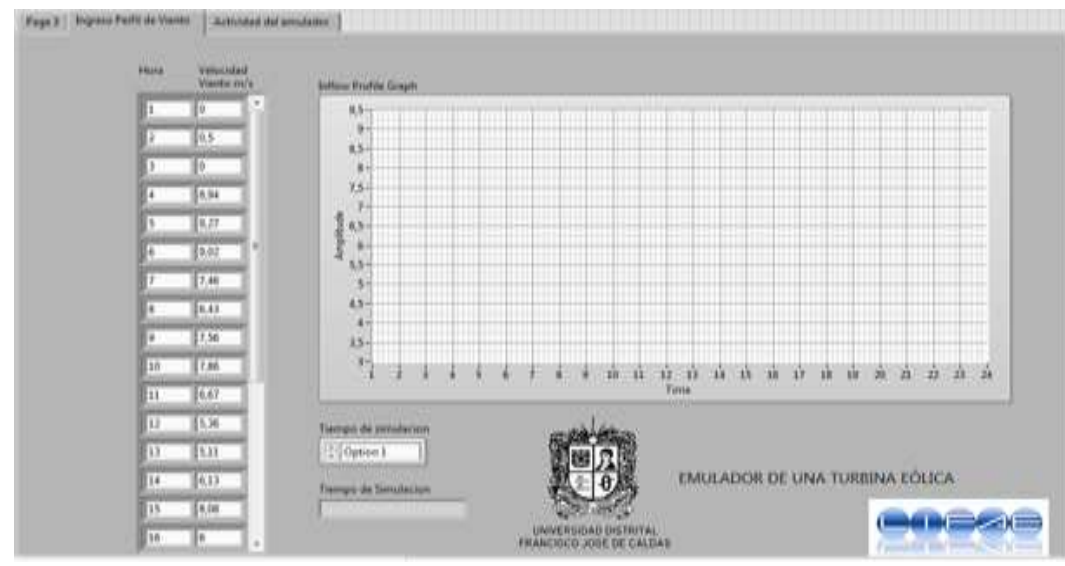

Fig. 7. The screen in which the wind profile is entered.

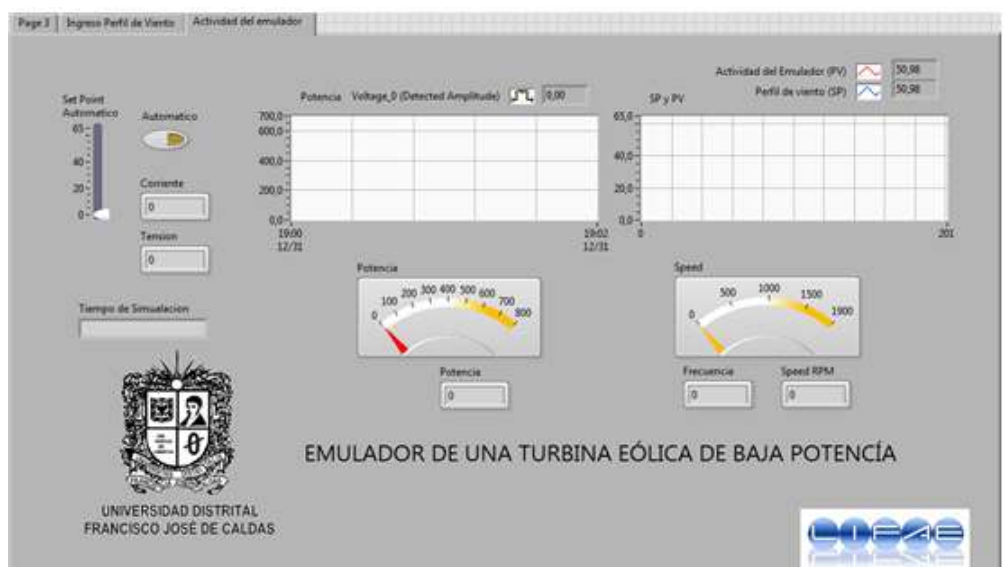

Fig. 8. The screen in which the emulator variables are displayed.

When executing the program, the emulator starts operating at the minimum speed (3 $\mathrm{m} / \mathrm{s}$, approximately), which is obtained for the frequency of $3 \mathrm{~Hz}$. At that particular moment, the graph of the loaded wind profile can be seen in the window presented in Fig. 7, as well as the option of the simulation time which can be of 1 minute, 10 minutes, 1 hour or in real-time. 
Fig. 9 shows the variables of interest measured in the emulator. These are as follows: speed, operation frequency, voltage, current and generated power. Additionally, there is an option to enable or disable the manual operation to control the rotation speed depending on the frequency. Additionally, it also displays the time at which the simulation is being performed.

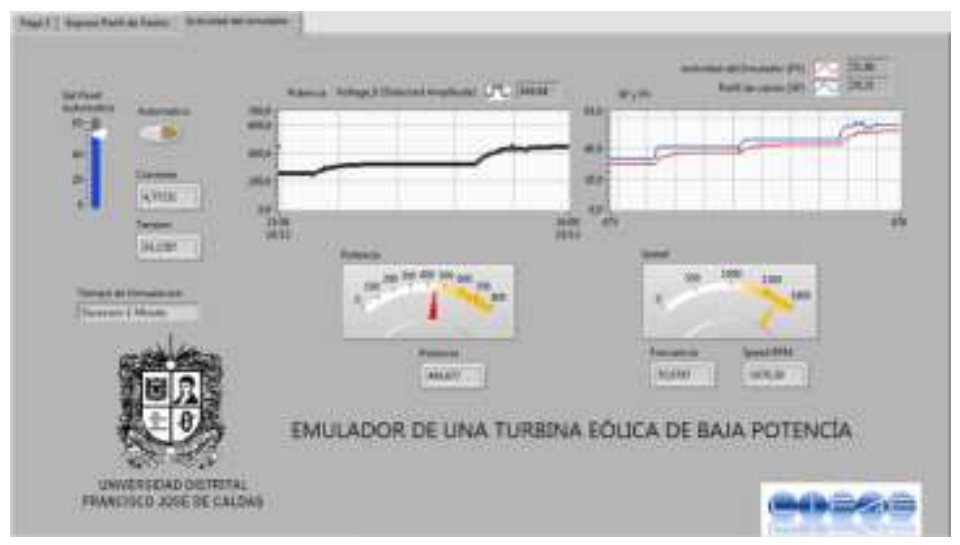

Fig. 9. Emulator behavior during the test in a manual mode according to the power curve given by the manufacturer of the chosen turbine.

This part of the program also shows the power curve which is being generated. On the right-hand side of such graph, two curves can be seen when the emulator is in operation, one being the setpoint, whereas the other one is the curve showing how the emulator is working.

\section{A. Manual test: Comparison with the Curve Provided by the Manufacturer of the Chosen Turbine Eolos $600 \mathrm{~W}$}

This first test consists of comparing the information provided by the manufacturer of the Eolos $600 \mathrm{~W}$ turbine with the data given by the emulator for the same wind speeds.

From the software, when enabling the manual option, the power values can be observed. Such values were obtained when entering the frequency corresponding to the wind values recorded in the power table given by the manufacturer of the Eolos $600 \mathrm{~W}$ turbine. Likewise, the power at the output of the prototype is measured. Fig. 9 shows an image of the graphic interface of the emulator whilst the previously 
described process was being conducted. Additionally, the power curves (black), the setpoint (blue) which changes as the selected frequency varies, as well as the behavior of the emulator (red) can also be seen.

Table 2 shows a comparison of the data provided by the manufacturer and those generated by the emulator.

Table 2. Comparison between the power results given by the manufacturer and those generated by the emulator.

\begin{tabular}{|c|c|c|c|}
\hline Frequency $\mathbf{( H z )}$ & Wind speed $\mathbf{( m / s )}$ & Turbine P. (W) & Emulator P. (W) \\
\hline 12 & 4 & 25 & 25.8 \\
\hline 15 & 5 & 40 & 35 \\
\hline 23 & 6 & 90 & 94.3 \\
\hline 25 & 7 & 110 & 112.5 \\
\hline 29 & 8 & 145 & 149.35 \\
\hline 33.5 & 9 & 190 & 195.69 \\
\hline 41 & 10 & 280 & 291.1 \\
\hline 46.5 & 11 & 350 & 349.97 \\
\hline 55.5 & 12 & 470 & 492.9 \\
\hline 59 & 13 & 525 & 548.89 \\
\hline 66 & 14 & 600 & 619.5 \\
\hline 59 & 15 & 530 & 544.5 \\
\hline 57 & 16 & 490 & 508.25 \\
\hline
\end{tabular}

With the obtained results in the tests reported in Table 2, the error was calculated and is presented in Table 3 .

Table 3. Error in the wind emulator.

\begin{tabular}{|c|c|c|}
\hline Turbine P. [W] & Emulator P. [W] & $\%$ Error \\
\hline 25 & 25.8 & $3 \%$ \\
\hline 40 & 41.3 & $3 \%$ \\
\hline 90 & 94.3 & $5 \%$ \\
\hline 110 & 112.5 & $2 \%$ \\
\hline 145 & 149.35 & $3 \%$ \\
\hline 190 & 195.69 & $3 \%$ \\
\hline 280 & 291.1 & $4 \%$ \\
\hline 350 & 349.97 & $0 \%$ \\
\hline 470 & 492.9 & $5 \%$ \\
\hline 525 & 548.89 & $5 \%$ \\
\hline 600 & 619.5 & $3 \%$ \\
\hline 530 & 544.5 & $3 \%$ \\
\hline 490 & 508.25 & $4 \%$ \\
\hline
\end{tabular}


Testing the emulator manually showed that, on average, it has an error margin of less than $6 \%$, one of the lowest error rates obtained throughout the development of the emulator.

Now, that the program test in manual mode has been completed, the next step is to verify the operation of the automatic mode. In such function, a 24-hour wind profile which had been previously established - is loaded in one of the windows of the graphic interface implemented in LabView. Subsequently, a test is presented in which the wind characteristics consigned in a wind profile are used. Such characteristics are taken from a specific point of the Colombian geography.

\section{B. Wind Profile: A Case Study in Colombia}

One of the options to test the operation of the emulator is to load a wind profile from a specific place for watching its behavior for different wind speeds at different times. It should be noted that speeds below $3 \mathrm{~m} / \mathrm{s}$ do not allow an adequate operation of the emulator. This is because the power generated is negligible.

Consequently, and to investigate new alternative energy sources that could help to expand the energy matrix in Colombia, the department of Guajira was chosen to select a geographic location whose environmental conditions were ideal for the exploitation of wind power. The selected location is the municipality of Uribía in the department of La Guajira, which is recognized for hosting the only existing wind farm in Colombia. The coordinates of this location are as follows: latitude 12.5, longitude -72.5 .

To enter the wind profile into the program, data with the coordinates of the place of interest were extracted from NASA's online database called Atmospheric Science Data Centre. The monthly average delivered by the atmospheric service is repeated so that it can be adjusted to the input times given in the Labview interface. The extracted data can be seen in Table 4. In addition to this, such data were entered as seen in Table 5. 
Table 4. Monthly average wind speed is given in coordinates of a municipality in La Guajira.

\begin{tabular}{|c|c|c|c|c|c|c|c|c|c|c|c|c|c|}
\hline Lat. 12.22 & Jan & Feb & Mar & Apr & May & Jun & Jul & Aug & Sep & Oct & Nov & Dec & $\begin{array}{c}\text { Annual } \\
\text { Avg. }\end{array}$ \\
\hline Lon. 72.15 & & & & & & & & & &
\end{tabular}

Table 5. The wind profile entered for the second simulation.

\begin{tabular}{|c|c|}
\hline Hour & Wind Speed [m/s] \\
\hline $00: 00$ & 8.94 \\
\hline $01: 00$ & 9.27 \\
\hline $02: 00$ & 9.02 \\
\hline $03: 00$ & 7.46 \\
\hline $04: 00$ & 6.46 \\
\hline $05: 00$ & 7.56 \\
\hline $06: 00$ & 7.86 \\
\hline $07: 00$ & 6.67 \\
\hline $08: 00$ & 5.36 \\
\hline $09: 00$ & 5.11 \\
\hline $10: 00$ & 6.13 \\
\hline $11: 00$ & 8.08 \\
\hline $12: 00$ & 8.94 \\
\hline $13: 00$ & 9.27 \\
\hline $14: 00$ & 9.02 \\
\hline $15: 00$ & 7.46 \\
\hline $16: 00$ & 6.46 \\
\hline $17: 00$ & 7.56 \\
\hline $18: 00$ & 7.86 \\
\hline $19: 00$ & 6.67 \\
\hline $20: 00$ & 5.36 \\
\hline $21: 00$ & 5.11 \\
\hline $22: 00$ & 6.13 \\
\hline $23: 00$ & 8.08 \\
\hline & \\
\hline
\end{tabular}

The profile is loaded into the program at the moment the simulation starts. Furthermore, the curve describing the profile can be seen in the first screen of the graphic interface, as shown in Fig. 10, in which the curve can be seen as well as the wind profile data located in the matrix placed on the left side. 


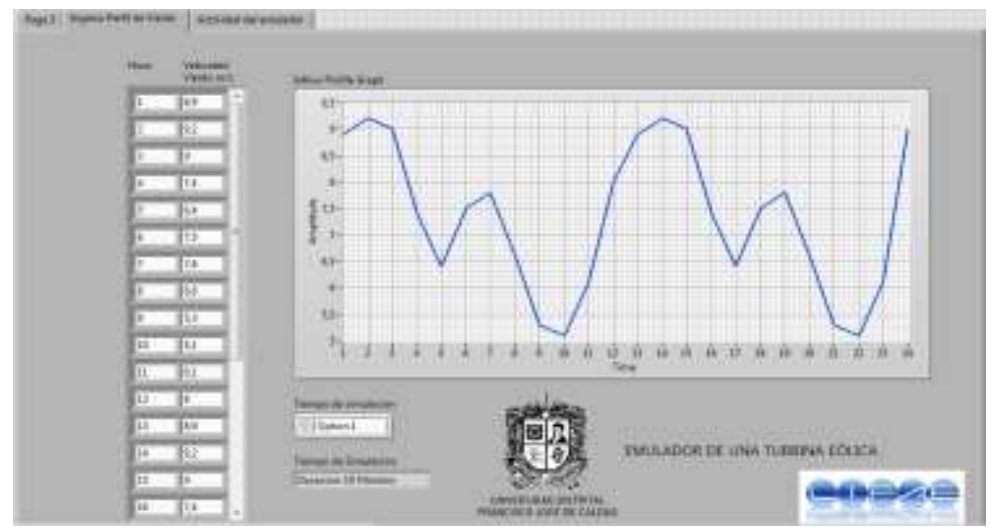

Fig. 10. Wind profile of Uribía-Guajira loaded in the emulator program.

As previously described, the simulation times can be changed. For instance, the wind profile with data from 24 hours of wind resource measurement can be reproduced in time of 1 minute, 10 minutes, one hour and real-time respectively. For this test, the obtained results in the simulations in one minute were recorded and such behavior can be seen in Fig. 11. Moreover, the 10-minute simulation time can be seen in Fig. 12.

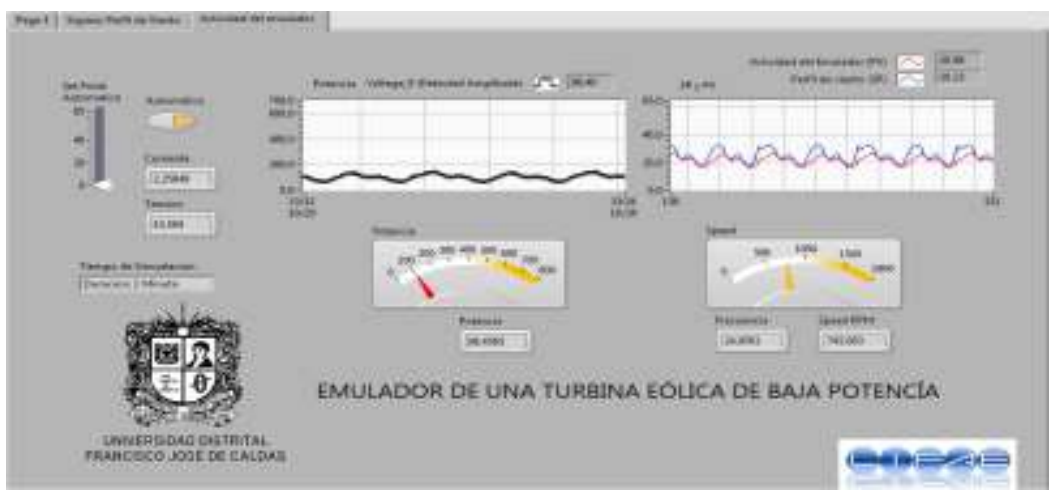

Fig. 11. Emulator behavior, reproducing the wind profile of the Guajira region and simulating it with a time of 1 minute. 


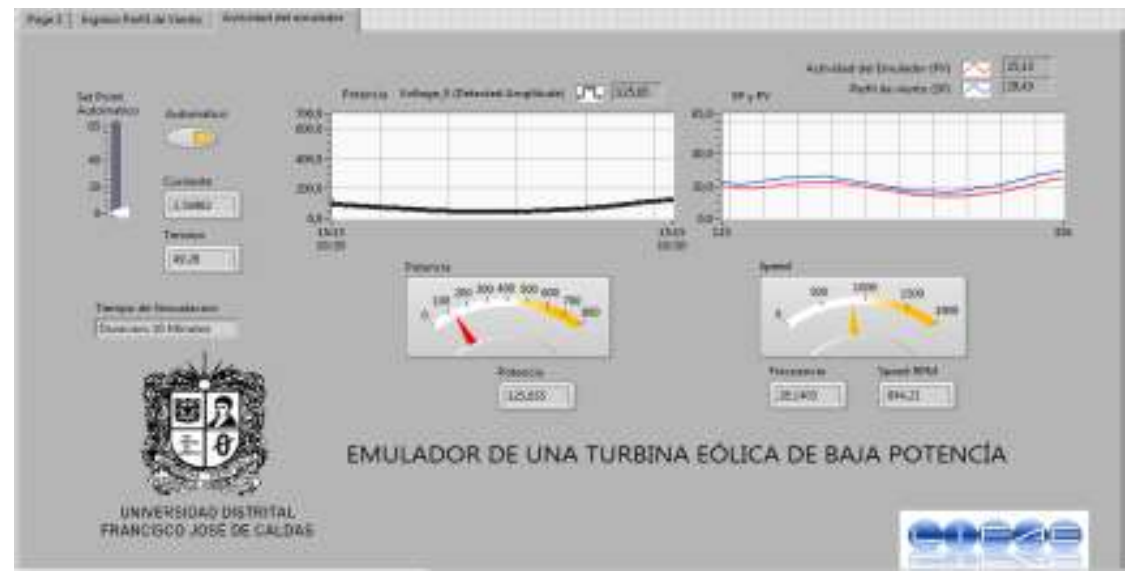

Fig. 12. Emulator behavior, reproducing the wind profile of the Guajira region and simulating it with a time of 10 minutes.

It can be seen how, on average, $100 \mathrm{~W}$ was generated during the test when loading the wind profile originating from the Guajira region. Furthermore, it can also be seen how the emulator neither manages to stabilize nor to equal the behavior of the loaded wind profile when simulating in a time of one minute - at least in considerable increases of the wind speed -, due to the speed with which it changes.

On the other hand, in the test with a simulation time of 10 minutes, the program has more time to do all the processing, which causes the curve showing the behavior of the emulator to look similar to that of the loaded wind profile, as seen in Fig. 12.

\section{CONCLUSIONS}

An emulator of a low power wind turbine was designed and implemented through the coupling of a three-phase induction motor and a permanent magnet generator. Such an emulator has a graphic interface developed in Labview which records its activity. Furthermore, it is in the graphic interface where the generated power can be visualized. Additionally, it allows the entry of wind profiles (wind speed vs time) which are processed together with the signals captured by the encoder of the permanent magnet generator to determine the error. Subsequently, such process allows its later entry to a PID block, whose constants were tuned through Ziegler-Nichols, in LabView - on the experimental response of the system - to control the variable of 
interest (speed) as well as determine the output power to be generated by the emulator, through its subsequent mathematical processing.

The system presents two operating options. One in which it is possible to load different speed data which are associated with a particular power taking into account the selected wind profile, whereas the second option of operation is manual control of the wind speed.

The test of the emulator in a manual way showed that on average, the emulator has an error margin less than $6 \%$, compared to the data provided by the turbine manufacturer, which makes the emulator a reliable element to operate in a controlled laboratory environment.

\section{AUTHOR'S CONTRIBUTION}

Trujillo-Rodríguez was the generator of the central idea of research and supervisor of the assembly and experimental verification of the prototype. Bajonero-Sandoval and Sanabria-Vargas developed the set-up and carried out the laboratory tests. All authors were in charge of drafting and validating the document.

\section{FUNDING}

This work has been partially financed by the Center for research and Scientific Development of Universidad Distrital Francisco José de Caldas (CIDC) (Project number: 2-5-596-19).

\section{REFERENCES}

[1] J. G. González-Hernández, and R. Salas-Cabrera, "Representation and estimation of the power coefficient in wind energy conversion systems," Revista Facultad de Ingeniería, vol. 28 (50), pp. 77-90, 2019. https://doi.org/10.19053/01211129.v28.n50.2019.8816

[2] F. Blaabjerg, Z. Chen, and S. B. Kjaer, "Power electronics as efficient interface in dispersed power generation systems," IEEE Transactions on Power Electronics, vol. 19 (5), pp. 1184-1194, 2004. https://doi.org/10.1109/TPEL.2004.833453

[3] Renewable Energy Policy Network for the 21st Century-REN21, Renewables 2015: Global Status, REN21 Secretariat, Paris, France, 2015.

[4] Global Wind Energy Council-GWEC, Global Wind Report 2014, Global Wind Energy Council, Brussels, Belgium ,2015.

[5] I. Khorsand, C. Kormos, E. G. Macdonald, and C. Crawford, "Wind energy in the city: An interurban 
David-Felipe Bajonero-Sandoval; Jeyson Sanabria-Vargas; César-Leonardo Trujillo-Rodríguez

comparison of social acceptance of wind energy projects," Energy Research \& Social Science, vol. 8, pp. 66-77, 2015. https://doi.org/10.1016/j.erss.2015.04.008

[6] Unidad de Planeación Minero Energética-UPME, Plan de Expansion de Referencia Generación Transmisión 2015-2029, Ministerio de Minas y Energía de Colombia, Bogotá, Colombia, 2016.

[7] I. Moussa, A. Bouallegue, and A. Khedher, "New wind turbine emulator based on DC machine: Hardware implementation using FPGA board for an open-loop operation," IET Circuits, Devices \& Systems, vol. 13 (6), pp. 896-898, 2019. https://doi.org/10.1049/iet-cds.2018.5530

[8] M. El Mokadem, V. Courtecuisse, C. Saudemont, B. Robyns, and J. Deuse, "Experimental study of variable speed wind generator contribution to primary frequency control," Renewable Energy, vol. 34 (3), pp. 833 844, 2009. https://doi.org/10.1016/j.renene.2008.04.033

[9] J. M. Guerrero, C. Lumbreras, D. D. Reigosa, P. Garcia, and F. Briz, "Control and Emulation of Small Wind Turbines Using Torque Estimators," IEEE Transactions on Industry Applications, vol. 53 (5), pp. 4863-4876, 2017. https://doi.org/10.1109/TIA.2017.2708027

[10] F. Martinez, L. C. Herrero, and S. de Pablo, "Open loop wind turbine emulator," Renewable Energy, vol. 63, pp. 212-221, 2014. https://doi.org/10.1016/j.renene.2013.09.019

[11] N. Thodsaporn, C. Choorak, and V. Kinnares, "Wind turbine simulator based grid connected asymmetrical two-phase induction generator," in 18th International Conference on Electrical Machines and Systems, 2016. https://doi.org/10.1109/ICEMS.2015.7385127

[12] Z. Dekali, L. Baghli, and A. Boumediene, "Experimental Emulation of a Small Wind Turbine under Operating Modes Using DC Motor," in 4th International Conference on Power Electronics and their Applications, 2019. https://doi.org/10.1109/ICPEA1.2019.8911194

Revista Facultad de Ingeniería (Rev. Fac. Ing.) Vol. 29 (54), e10530. 2020. Tunja-Boyacá, Colombia. L-ISSN: 0121-1129, e-ISSN: 2357-5328, DOI: https://doi.org/10.19053/01211129.v29.n54.2020.10530 